\title{
EFFECT OF SILICA ON PHYSIOLOGICAL AND ULTRASTRUCTURE CHARACTERS IN BARLEY (HORDEUM VULGARE L.) PLANT UNDER SALT STRESS
}

\author{
Hend A. El-khawaga \\ Botany and Microbiology Department, Faculty of Science, Al-Azhar University (Girls Branch), Cairo, \\ Egypt
}

\begin{abstract}
Salt stress is one of several major abiotic stresses that affect plant growth and development, and there are many evidences that silicon can ameliorate the injuries caused by high salinity. This study presents the results of an assay concerning: (1) the effect of $\mathrm{NaCl}$ induced salt stress in barely plant (cultivar Giza 123) and (2) the possible mitigating effect of silicon in saline conditions. In these study, different concentrations of $\mathrm{NaCl}(200 \&$ $300 \mathrm{mM})$ used singly or in combination with silicon $(0.5 \& 1.0 \mathrm{mM}$ potassium silicate). Morphological characters of shoot and roots, membrane stability index, relative water content, sodium, potassium, silica, photosynthetic pigments content and some antioxidant enzymes, as well as leaf electron microscope were evaluated. The results showed that, all parameters analyzed decreased except antioxidant enzymes and sodium content were drastically increased by increased salt levels. The supply of silicon (1mM) has successfully mitigated the effect of salinity at $300 \mathrm{mM} \mathrm{NaCl}$. In conclusion, we affirmed that, salt stress is harmful for cape barley plants and the addition of silicon showed effective in mitigating the saline effects.
\end{abstract}

Key words: Hordeum vulgare L., salt stress, silicon, physiological and ultrastructure characters.

\section{INTRODUCTION}

Salt stress is considered one of the major abiotic stresses that can limit the plant growth and productivity (Zhu and Gong, 2014). The impacts of high salinity involve decline in crop yields, reduced water use efficiency, land disuse, contamination of environment and less food supply (FAO, 2017).

Salinity is a major stress condition at present (Rueda-Puente et al., 2007) and is one of the most serious environmental problems influencing crop growth (Lopez et al., 2002) and together with drought continues to be one of the world is most serious environmental problems in agriculture. This problem is particularly serious in arid and semi-arid regions of the world where most of the developing countries happen to fall (Khan et al., 1999). Salinity causes not only differences between the mean yield and the potential yield, but also causes yield reduction from year to year. It affects the plant growth directly through its interaction with metabolic rates and pathways with in the plants. Long considered by plant physiologist as a nonessential nutrient, the importance of silicon $(\mathrm{Si})$ has only recently been recognized (Richmond and Sussman, 2003). Silicon is non-essential element for plant growth, however, various studies have demonstrated that $\mathrm{Si}$ application significantly increased plant growth under normal (Agurie $e t$ al.,1992) and stresse condition including biotic and abiotic stresses as salt stress (Ma, 2004). A number of possible mechanisms are proposed through which $\mathrm{Si}$ may increase salinity tolerance in plants, e.g., improving water status (Romero et al., 2006), increased photosynthetic activity and ultrastructure of leaf organelles (Shu and Lui, 2001), stimulation of antioxidant system (Zhu et al., 2004), and alleviation of specific ion effect by reducing $\mathrm{Na}$ uptake (Liang et al., 2003) or by H-ATPase dependent enhancement in $\mathrm{K}$ in shoots (Liang et al., 2005). Gong et al., (2003) also observed improved water economy and dry matter yield of plants by Si application.

Silicon is recognized as quasi-essential element for plants because its deficiency results in various dysfunctions with respect to plant 
growth and proliferation (Hasanuzzaman et al., 2013). Silicon acts as plant protectant, plays a pivotal role in enhancing the plants growth and productivity especially in stress condition (Sawas and Ntatsi 2015) The ameliorative role of silicon to adverse effects of drought has been reported in different crops such as rice (Hakim et al 2012), sugarcane (Bokhtiar et al 2012) and wheat (Tahir et al., 2006).

Barley (Hordeum vulgare L.) is a highly adaptable cereal grain and ranks $5^{\text {th }}$ among all crops for dry matter production in the world. Therefor barley is an important food source in many parts of the world (Newman and Newman 2006). Barley is considered to be the most drought and salinity tolerant among cereals and the most important crop species in the world. Barley is tolerant to salinity (Chen et al., 2007), so is a good candidate for use in saline discharge areas. However, barley is sensitive to waterlogging (Zhou et al., 2012).

In view of the importance of $\mathrm{Si}$ in salt tolerance, it is hypothesized that $\mathrm{Si}$ can protect plant against effect of salinity stress. Therefore, the main objective of this study to investigate the effect of $\mathrm{Si}$ on some physiological and ultrastructure properties of barely plant under salinity stress conditions.

\section{MATERIALS AND METHODS}

A pot experiment was carried out during winter season of 2016-2017 at a fenced area under the prevailing environmental conditions, Faculty of Agriculture, Al-Azhar University at Nasr City, Cairo, Egypt to investigate the interaction effect between silica and sodium chloride on some growth characters, membrane stability index, relative water content, sodium, potassium, silica content, photosynthetic pigments, some antioxidant enzymes and leaf ultrastructure.

The seeds of barley plant (cultivar Giza 123) were obtained from Agriculture Research Centre after being sterilized with $5 \%$ sodium hypochlorite for $5 \mathrm{~min}$. to prevent fungal attack and then rinsed with sterile water. Planting was done in plastic pots $(25 \mathrm{~cm}$ in diameter and 24 $\mathrm{cm}$ in height), each pot was filled with $7 \mathrm{~kg}$ of sandy loam soil. The total number of pots were 42 (6 pots per treatments). The pots were designed as a complete randomized pattern with five replicates for each treatment. Ten seeds were sown in each pot. The seeds were directly planted at depth of $1.5 \mathrm{~cm}$ from the soil surface. After complete emergence (two weeks from sowing date), seedling was thinned to 5 identical ones in each pot. Irrigation was monitored at $60 \%$ of water holding.

\section{Silica and salinity treatments}

Sodium chloride was added in two concentrations $(200 \& 300 \mathrm{mM})$, to avoid osmotic shock of salinity, saline treatment was imposed incrementally by increasing the concentration of $25 \mathrm{mM}$ every day until the final concentration was reached. A factorial experiment based on completely randomized design with 2 levels of $\mathrm{Si}(0.5$ and $1 \mathrm{mM})$. Potassium silicate was used for silica treatment. Salt and silica treatments started at 30 days after planting. A control group of plants was grown without $\mathrm{NaCl}$ and silica and irrigated with Hoaglands stock solution according to Hoagland and Arnon (1950). All plants were harvested 45 days after planting and separated into root, stem and leaf.

\section{Growth measurements}

Shoot and root length $(\mathbf{c m})$ : Ten plants from each treatment were chosen randomly to measure morphological parameters. Roots and shoot length were measured of each replicate with help of scale.

Dry weight (g): The plant shoots and roots for each treatment were rinsed with distilled water then dried in an oven at $70^{\circ} \mathrm{C}$ till a constant dry weight was obtained; the dry weights were calculated as $\mathrm{g} / \mathrm{plant}$.

Membrane stability index (MSI): Membrane stability index was determined according to (Sairam and Srivastava 2002) and expressed as \%. 
Relative water contents (RWC): Relative water contents was determined according to Ritchie and Nguyen (1990) and expressed as \%.

Photosynthetic pigments: Chlorophyll a, b and carotenoids were determined according to Metzner et al., (1965) and expressed as mg/g f wt.

Determination of Sodium and Potassium in barley leaves: The method of extraction was carried out by Chapman and Pratt (1961). The acid digest of plant materials was analyzed for the determination of sodium and potassium.

Sodium and Potassium: Sodium and potassium were determined photometrically using Flam Photometer Corning 400. Results were expressed as $(\mathrm{g} / 100 \mathrm{gm})$ dry weight of the plant materials

Determination and estimation of silica: Silica determined according to (Elliot and Synder, 1991) and expressed as mg/g dry wt.

Enzymes extraction and assay: The leaf samples weighing about $200 \mathrm{mg}$ were homogenized with $10 \mathrm{ml}$ phosphate buffer $\mathrm{pH}$ 6.8 (0.1). Five $\mathrm{ml}$ of homogenate was centrifuged at $2 \mathrm{C}^{0}$ for $15 \mathrm{~min}$. at $17.000 \mathrm{~g}$ in a refrigerated centrifuge. The clear supernatant was taker as the enzyme source.

Assay of Catalase (CAT): Catalase activity (EC1.11.1.6) was assayed following by the method of Cakmak and Marschner (1992) and expressed as enzyme unit $\mathrm{g}^{-1} \mathrm{f} \mathrm{wt}$.

Assay of Peroxidase (POX): POX activity (EC 1.11.1.7) was assayed by the method of McCune and Galston (1989) and expressed as enzyme unit $\mathrm{g}^{-1} \mathrm{f}$ wt.

Assay of Ascorbate peroxidase (APX): Ascorbate peroxidase (EC 1.11.1.11) activity was measured according to Nakano and Asada (1987) and expressed as enzyme unit $\mathrm{g}^{-1} \mathrm{f}$ wt.

\section{Transmission Electron Microscopy}

The fully expanded uppermost leaves of barley were collected and fixed for $3 \mathrm{~h}$ at room temperature with $2 \%$ glutaraldehyde in 100 $\mathrm{mM}$ sodium cacodylate buffer with a $\mathrm{pH}$ value of 7.4 (Sabatini et al., 1963). Samples were post-treated in $1 \%(\mathrm{w} / \mathrm{v}) \quad \mathrm{OsO}_{4}$, similarly buffered for $6 \mathrm{~h}$ at room temperature, dehydrated in a graded ethanol series and propylene oxide, and infiltrated and embedded in Spurr's epoxy resin (Spurr, 1969). Ultrasections were obtained using a LKBV ultramicrotome and stained with uranyl acetate and lead phosphate. Images were observed and generated using a transmission electron microscope (JEM-1230 JEOL, Japan). The size of the intercellular space and cell wall was measured manually on the printed micrographs. Transmission electron microscope carried out at the Regional Center for Mycology and Biotechnology (RCMB), Al-Azhar University. The investigation was carried out at $70 \mathrm{KV}$.

Statistical analysis: The statistical analysis was performed for each parameter, and the values compared as per least significant difference test at $\mathrm{p}<0.05$. All statistical analyses were carried out using the SAS program, (SAS, 2004).

\section{RESULTS AND DISCUSSIONS}

\section{plant: \\ Morphological characters of barley}

As shown in the figures (1-6), the growth characters; shoot and root fresh \& dry weights and their lengths of barely plant were significantly reduced by $\mathrm{NaCl}$ stress; however, this inhibition was significantly alleviated by $\mathrm{Si}$ supplementation, under salt stress $\mathrm{Si}$ significantly increases the growth characters of shoot and root of barely plant comparing to control. The highest increase in all growth characters was observed at $1 \mathrm{mM} \mathrm{Si}$ in combination with $\mathrm{NaCl}$ at $200 \mathrm{mM}$ it significantly increased by $28.8,13,24.7,32$, 13.4 and 4.03 for $\mathrm{f}$ wt., dry wt. as well as length of root and shoot, respectively. Improvement of salt tolerance by addition of $\mathrm{Si}$ have been reported in barley (Liang et al., 2003), wheat (Ahmad et al., 1992) and tomato (Al-Aghabary et al., 2004). The present results were consistent with previous findings. The growth of salt-stressed barely plants was significantly 
improved by addition of $\mathrm{Si}$. It has been reported that the alleviation of salt toxicity by $\mathrm{Si}$ addition are due to reduction of $\mathrm{Na}$ content in shoot of rice (Yeo et al., 1999 and barley (Liang et al., 2003), enhanced K uptake of barely (Liang 1998) and improved photosynthesis rate in barely and tomato (AlAghabary et al., 2004). Enhancement of growth

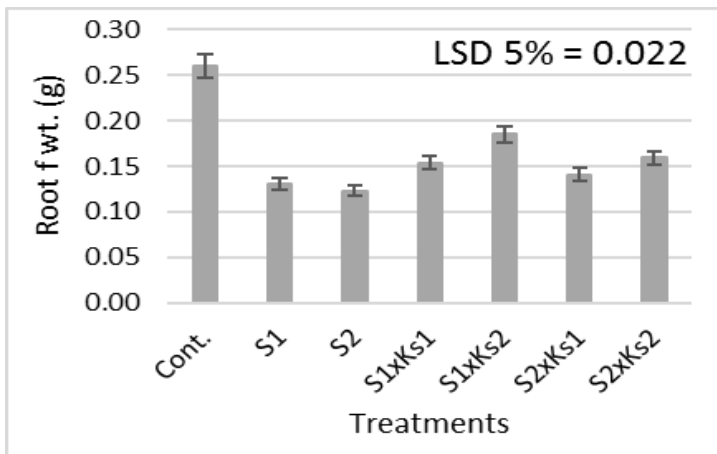

Fig 1. Interaction effect of salinity and silica on root fresh weight of barley plant.

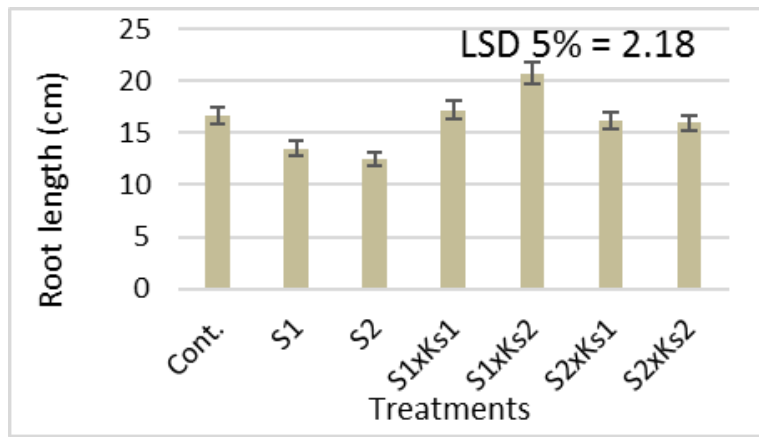

Fig 3. Interaction effect of salinity and silica on root length of barley plant.

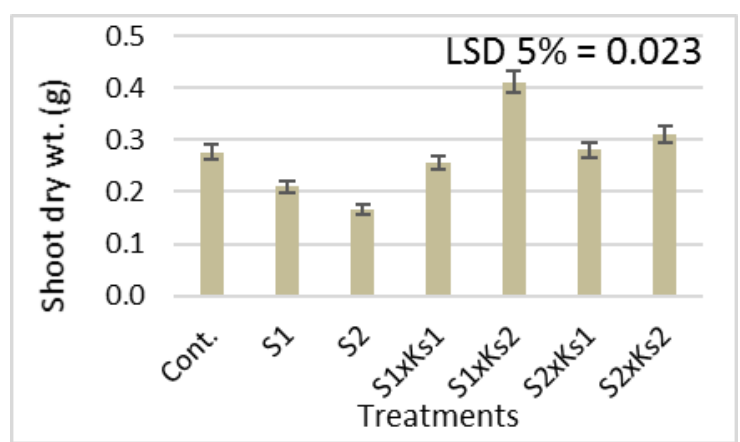

Fig 5. Interaction effect of salinity and silica on shoot dry weight of barley plant. characters increased by $\mathrm{Si}$ addition under stress condition attributed to $\mathrm{Si}$ increases rigidity of mature leaves which have rougher texture and are held more horizontally, delay leaf senescence and increase chlorophyll content as well as ribulose bisphosphate carboxylase activity. It has been observed that $\mathrm{GA}_{1}$ and its precursor $\mathrm{GA}_{20}$ enhanced with $\mathrm{N}$ and $\mathrm{Si}$

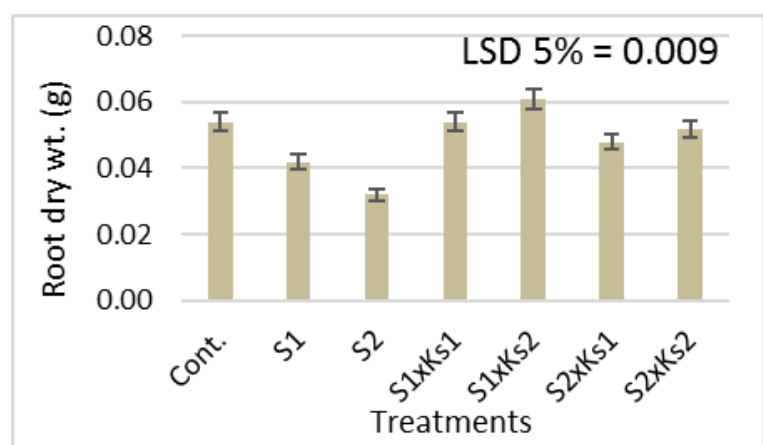

Fig 2. Interaction effect of salinity and silica on root dry weight of barley plant.

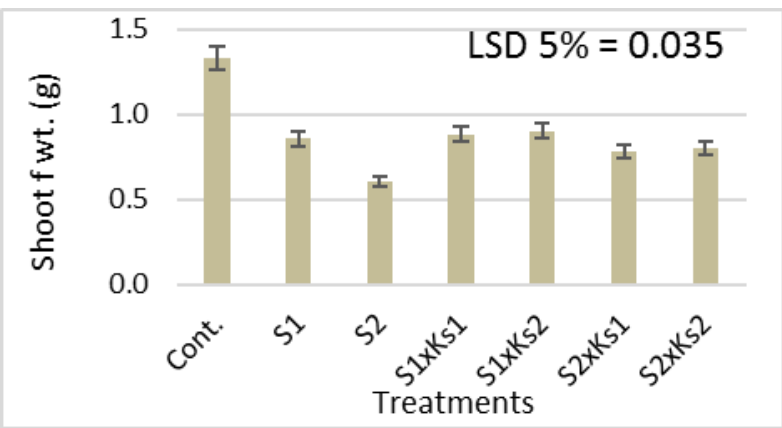

Fig 4. Interaction effect of salinity and silica on shoot fresh weight of barley plant.

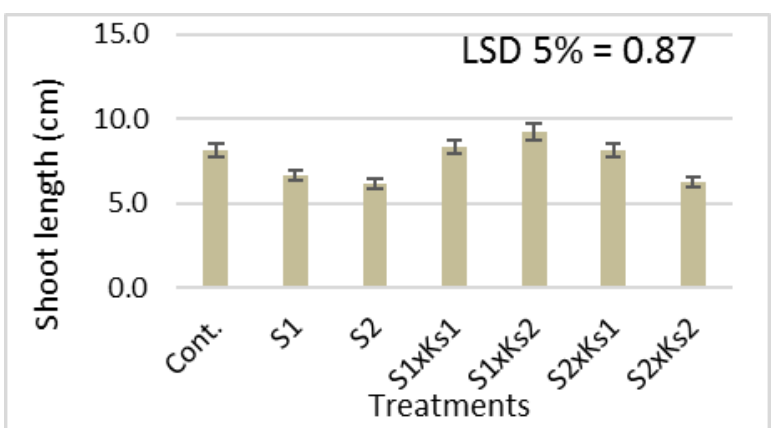

Fig 6. Interaction effect of salinity and silica on shoot length of barley plant.

Cont= control, $\mathrm{S} 1=200 \mathrm{mM} \mathrm{NaCl}, \mathrm{S} 2=300 \mathrm{mM} \mathrm{NaCl}, \mathrm{Ks} 1=0.5 \mathrm{mM}$ Potassium silicate, $\mathrm{Ks} 1=1 \mathrm{mM}$ Potassium silicate 
application in rice cultivars. Gibberellins affect cell enlargement and division which leads to internode elongation in stems and increases stem height.

\section{Membrane stability index (MSI)}

Data in Fig. (7) are shows that, there was a significant effect between salinity treatment and silica application on membrane stability index (MSI). It decreased significantly with increase salinity levels. The toxic effect of salinity ameliorated by $\mathrm{Si}$ application. The highest values of MSI were recorded in plants grown under $200 \mathrm{mM} \mathrm{NaCl}$ and $1 \mathrm{mM}$ potassium silicate.

As the initial sites of cell injury by any environmental stress firstly appears in cell membrane (Ashraf and Ali 2008). Farooq and Azam (2006) reported that cellular injury increased with increasing salinity level in wheat varieties. Previous findings showed that addition of $\mathrm{Si}$ increased MSI of leaf cells, However, supply of $1 \mathrm{mM}$ potassium silicate increase MSI of barely plants (1.23\%) leaf cells. Electrolyte leakage affect dry matter accumulation mainly through osmotic imbalance and entrance of toxic ions.

\section{Relative Water Content (RWC)}

Increasing salinity levels significantly decreased RWC (Fig. 8), furthermore, in the combined treatments of potassium silicate $(1 \mathrm{mM})$ and sodium chloride at salinity level $200 \mathrm{mM}$ led to a significant increase in RWC in leaves of barely plant (1.04\%). Decrease in leaf water potential under salinity conceivably reduces expansive growth (Munns and Tester 2008). Decreased transpiration and improved light interception characteristics by keeping the leaf blade erect by $\mathrm{Si}$ application have been reported in some previous studies (Mali and Aery, 2008).

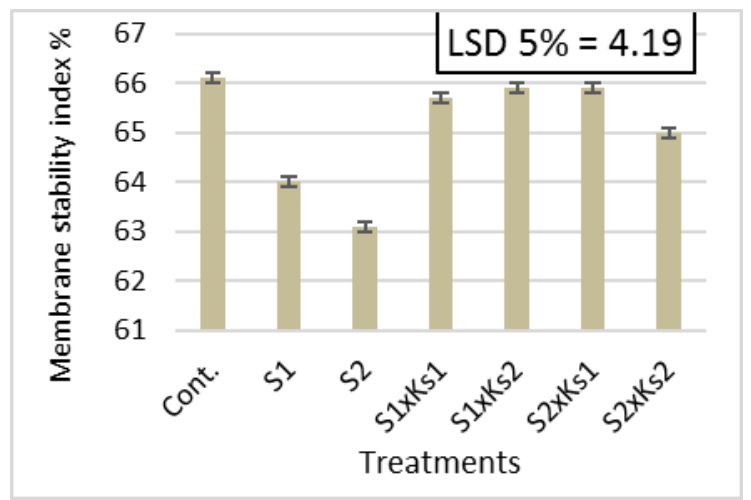

Fig. 7. Interaction effect of salinity and silica on membrane stability index of barley leaf.

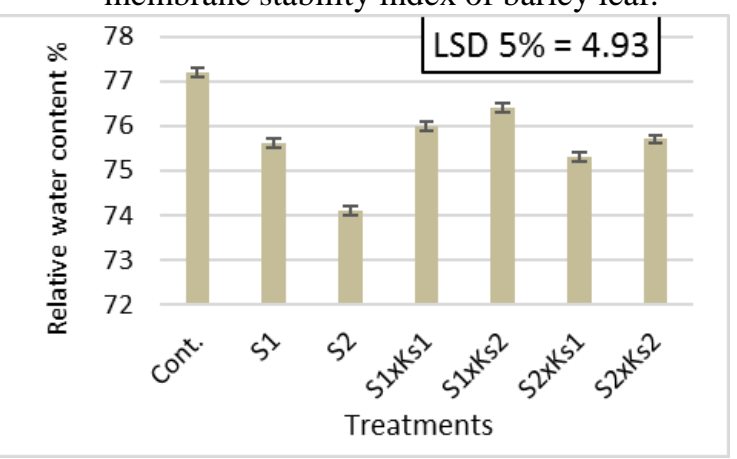

Fig. 8. Interaction effect of salinity and silica on relative water content $\%$ of barley leaf.

\section{Photosynthetic pigments content}

The addition of $\mathrm{NaCl}$, regardless of its concentration, reduced photosynthetic pigments contents in leaves of barely leaf (Figs. 9-13). The total pigments, for example, decreased by about 8.22 and $13.0 \%$ at $200 \& 300 \mathrm{mM} \mathrm{NaCl}$ respectively comparing to control, the same result was observed in cultivars of rice as well as cape goosebelly regenerated in vitro grown in presence of $\mathrm{NaCl}$ (Rezende et al., 2018). The decrease in chlorophyll contents in salt-stressed plants can be attributed to insufficiency of essential nutrients and inhibition of nutrients uptake (Srinieng, 2015). Many authors suggested that the decrease in chlorophyll levels may be due to inhibition of chlorophyll synthesis together with the increased activity of chlorophyll degrade enzyme chlorophyllase (Santos, 2004). Reactive oxygen species (ROS) that formed in salinity condition also cause the chlorophyll degradation and the loss of pigment is considered one of oxidative damage indicators (Yasar, 2008) The result obtained 
from treatments with supplementation with $\mathrm{Si}$, it is possible to note that this element was able to increase the content of ch a, b and carotenoid as well as total pigments under effect of $\mathrm{NaCl}$ treatment this improvement is related to occurrence of anatomic changes as reported by Asmar (2011), who observed an increase in

contents of chl. a, b in sage leaves under lower concentration of $\mathrm{NaCl}$ and presence of $\mathrm{Si}$. In higher concentration of salt, the pigments content was not increased, even when used high

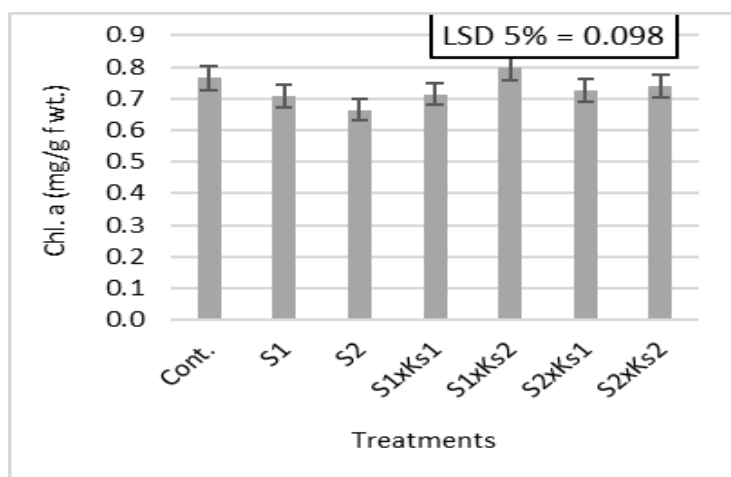

Fig. 9. Interaction effect of salinity and silica on chl. a of barley leaves.

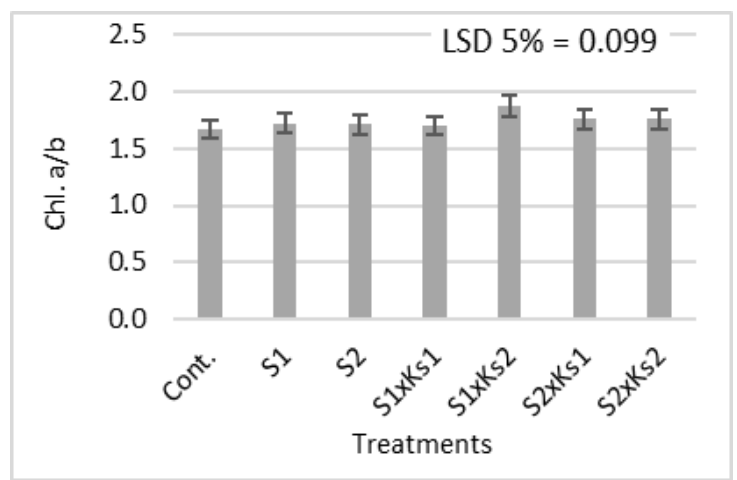

Fig. 11. Interaction effect of salinity and silica on chl. a/b of barley leaves.

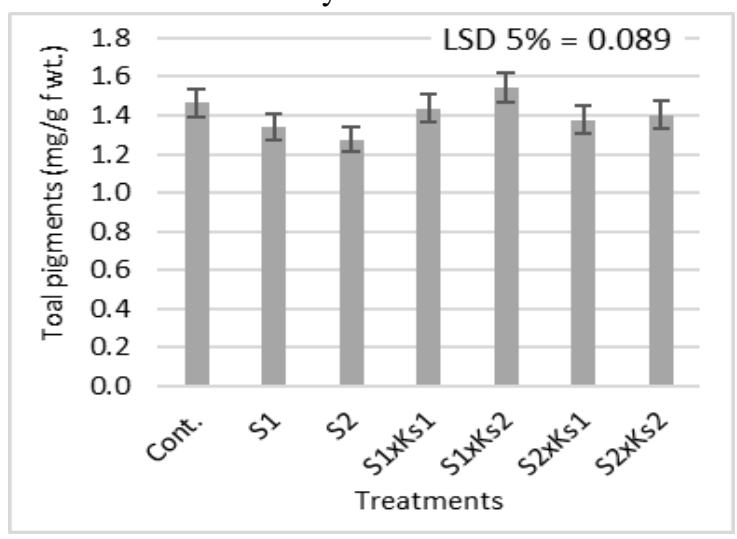

Fig. 13. Interaction effect of salinity and silica on total pigments of barley leaves. doses of Si. However, according to Currie and Perry (2007), even the plant not being able to accumulate Si due to some Kind of mechanism that hinders the absorption of this element, the absorption of $\mathrm{Si}$ can be triggered by stimulation of protection against diseases pests and other stress conditions.

\section{Sodium and potassium concentrations of barely leaves.}

Tissue content of $\mathrm{Na}$ increased considerably in response to salt treatments (Fig.

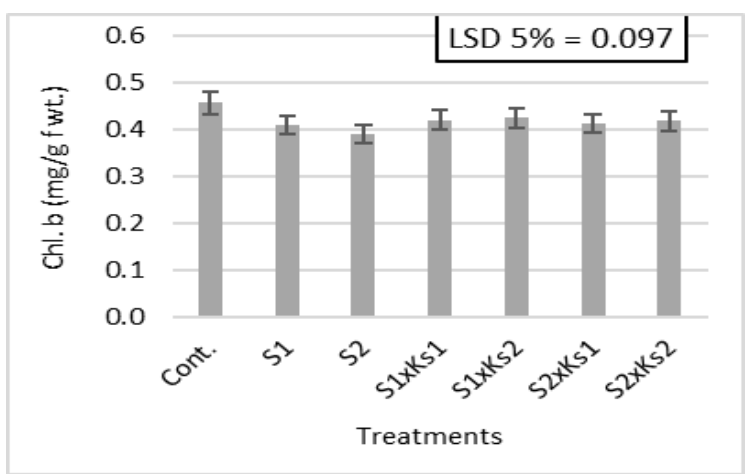

Fig. 10. Interaction effect of salinity and silica on chl. b of barley leaves.

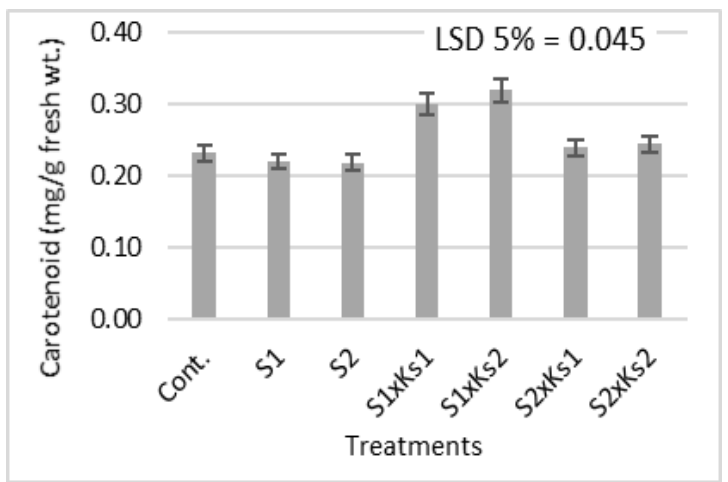

Fig. 12. Interaction effect of salinity and silica on carotenoid of barley leaves. 
14). The application of $\mathrm{Si}$ significantly decreased $\mathrm{Na}$ content at salinity level including $100 \& 200 \mathrm{mM} \mathrm{NaCl}$. The experiment has shown how the addition of $\mathrm{Si}$ to soil can ameliorate negative effect of salinity on growth and important ecophysiological parameters connected with it, as well as reduce $\mathrm{Na}$ and $\mathrm{cl}$ content in plant tissue. These results in agreement with the theory according to which silicon could limit salt stress by partially blocking the apoplastic transport, which is responsible of the main part of $\mathrm{Na}$ through plant roots (Garcia et al., 1997).

The data in Fig. (15) shows that salt stress considerably reduced the barely shoot $\mathrm{K}^{+}$ concentration in comparison to non-stress conditions. The $\mathrm{K}^{+}$content increased with increasing rate of $\mathrm{Si}$ under saline and Non saline conditions. Maximum concentration was observed in plants where silica was applied at $1 \mathrm{mM}$ potassium silicate. Increased $\mathrm{K}^{+}$ concentration shows the ability of plant to combat the salinity stress which depend strongly upon $\mathrm{Na}^{+}$and $\mathrm{Si}$ content. Silica uptake is positively correlated with $\mathrm{K}^{+}$and negatively with Na uptake. Possibly, the $\mathrm{K}^{+}$transport was improved by Si application by its effect on the flux through $\mathrm{K}^{+}$ion transporters. Liang et al., (1999) found that salt tolerance due to $\mathrm{Si}$ application is attributed to selective uptake and transport of $\mathrm{K}^{+}$and $\mathrm{Na}^{+}$by plants. Fig. 16 indicates that when barely plants were exposed to salt stress, $\mathrm{K}^{+}$: $\mathrm{Na}^{+}$was badly affected leading towards reduced uptake of $\mathrm{K}^{+}$as compared to $\mathrm{Na}^{+}$salt stress significantly reduced the $\mathrm{K}^{+}: \mathrm{Na}^{+}$in barely cultivar when compared with non-stress conditions. $\mathrm{K}^{+}: \mathrm{Na}^{+}$ increased with increase in exogenous Si under saline and non-saline conditions.

The significant increase of $\mathrm{Na}$ in leaves tissues of barely plants at high salt concentration and decrease $\mathrm{K} / \mathrm{Na}$ ratio in the leaves with increase in salinity suggests that $\mathrm{Na}^{+}$was transported in greater proportion than $\mathrm{K}^{+}$to this organ (Fig. 16). It is reported that uptake mechanisms of both $\mathrm{K}^{+}$and $\mathrm{Na}^{+}$are similar (Niu et al., 1995).

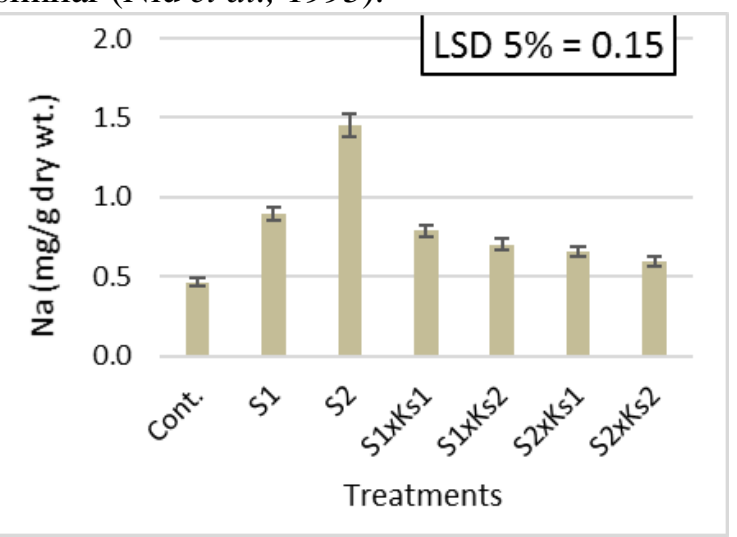

Fig. 14. Interaction effect of salinity and silica on $\mathrm{Na}$ content of barley leaves.

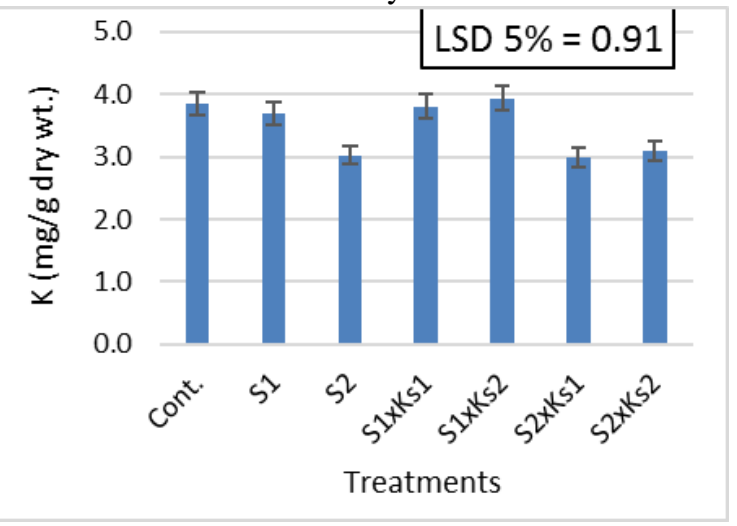

Fig. 15. Interaction effect of salinity and silica on $\mathrm{K}$ content of barley leaves.

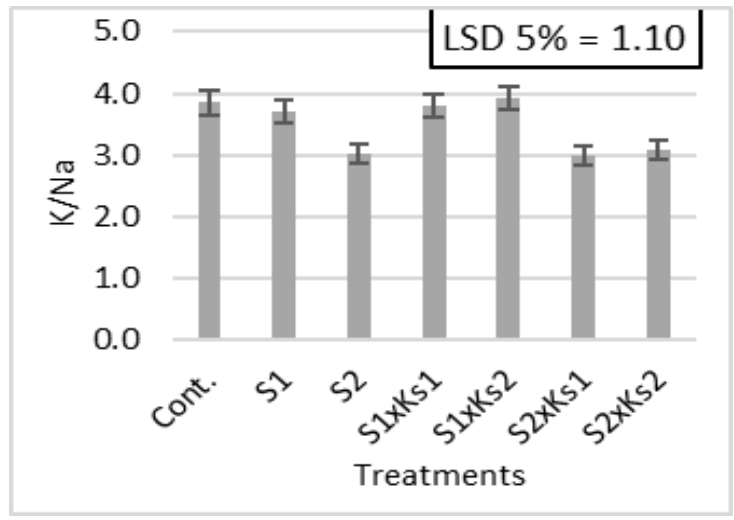

Fig. 16. Interaction effect of salinity and silica on

$\mathrm{K} / \mathrm{Na}$ of barley leaves.

Application of $\mathrm{Si}$ alleviated the adverse effect of high salinity on plants and improved. Effect salinity and silicon on root characteristic, growth, water $\mathrm{K}$ content in leaves and root, decrease $\mathrm{Na}$ content and increase $\mathrm{K} / \mathrm{Na}$ ratio in 
leaves. It seems that $\mathrm{Si}$ limits $\mathrm{Na}$ absorption and enhances $\mathrm{K}$ and consequently protecting the $\mathrm{K} / \mathrm{Na}$ ratio in high levels allowing safe growth.

\section{Silica concentration of barely leaves.}

Silica uptake (Fig. 17) was limited by addition of $\mathrm{NaCl}$ levels into the soil. The silica content of barely leaves increased with increasing rate of $\mathrm{Si}$ under saline conditions. Maximum concentration was observed in plants where $\mathrm{Si}$ was applied at $1 \mathrm{mM}$ potassium silicate, it significantly increased by $46.4 \%$. Silica uptake is positively correlated with $\mathrm{K}^{+}$ and negatively with Na uptake (Ali et al., 2009)

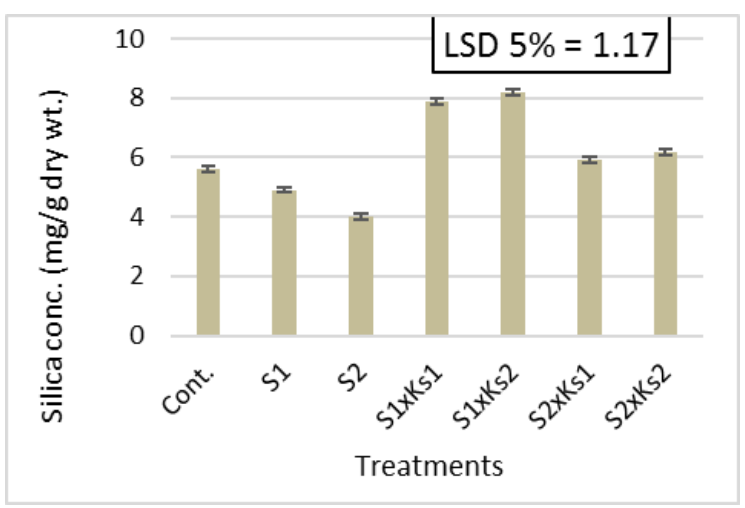

Fig. 17. Interaction effect of salinity and silica on silica content of barley leaves.

\section{Antioxidant enzymes}

Antioxidant enzymes catalase (CAT), peroxidase (POX) and ascorbate peroxidase (APX) are the main enzymes of antioxidant defense system which help in scavenging of lethal reactive oxygen species (ROS). These defense enzymes act as stress markers. The activities of antioxidant enzymes (CAT, POX and APX) were significantly increased in leaves of barely plants in response to potassium silicate when added singly or in combination with $\mathrm{NaCl}$ Although, significant increase was observed in all treatments in comparison to control but maximum increase stimulation was recorded for CAT, POX and APX) activities at salinity $(200 \mathrm{mM} \mathrm{NaCl}$ combined with potassium silicate (1mM) (Figs. 18-20).

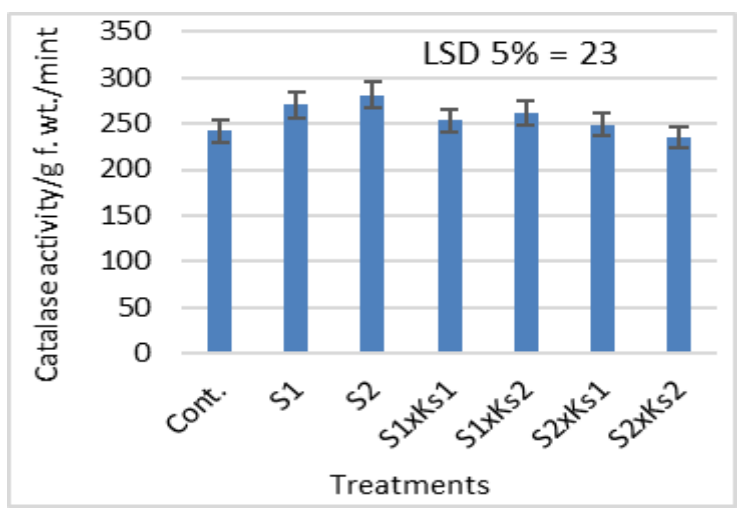

Fig. 18. Interaction effect of salinity and silica on catalase activity/g f wt./mint of barley leaves.

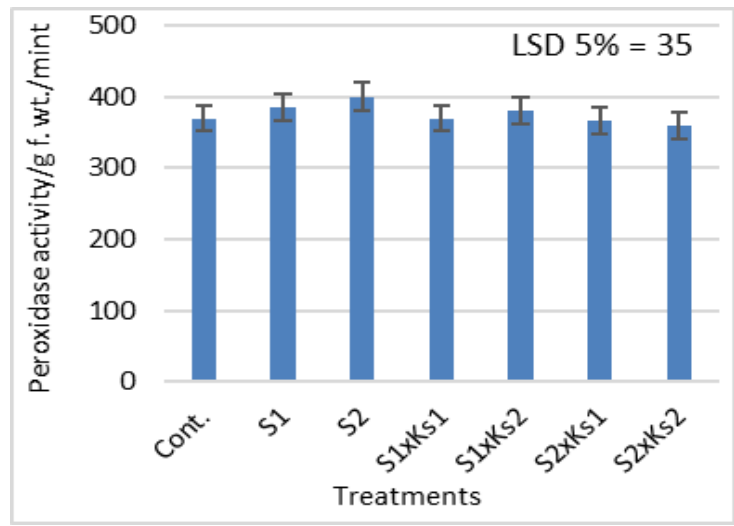

Fig. 19. Interaction effect of salinity and silica on peroxidase activity/g f wt./mint of barley leaves.

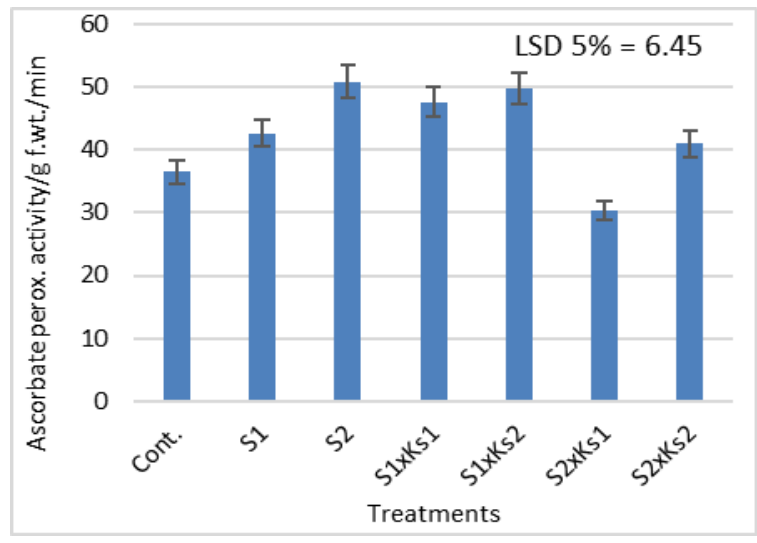

Fig. 20. Interaction effect of salinity and silica on Ascorbate perox. activity/g f wt./mint of barley leaves. 
The present study reveals that catalase (CAT), ascorbate peroxidase (APX) and peroxidase (POX) work synergistically in scavenging ROS species in barley plant under salt stress. Several enzymes of the defense system increased tremendously during salt stress in order to avoid the damage caused by reactive oxygen species (Ghahfarokh et al 2015). Ahmad and Haddad (2011) reported that application of silicon under salt stress significantly increased the activities of SOD, CAT and APX enzymes in wheat. Catalase in peroxisomes and APX in the cell as whole have potential to convert $\mathrm{H}_{2} \mathrm{O}_{2}$ into water and oxygen (Noctor and Foyer 1998). Shao et al. (2007) reported that CAT is the principal enzyme that scavenges $\mathrm{H}_{2} \mathrm{O}_{2}$ in cells. The combined action of CAT and SOD also converts the toxic O2 into $\mathrm{H}_{2} \mathrm{O}_{2}$ then into water and molecular oxygen, averting the cellular damage under water stress condition (Reddy et al., 2004). The increased activities of SOD and CAT were observed in various plants like cucumber Omidi (2010) and mustard (Romero et al., 2005) under abiotic stress condition. The increase in the antioxidant level was reported with increase in abiotic stress intensity in maize and soybean, Oracaz et al., (2007).

\section{Leaf ultrastructure}

Figure (21) shows transmission electron microscope micrograph of control, $\mathrm{NaCl}$ treated leaf as well as interactive effect between salinity and potassium silicate. There was no significant difference in leaf ultrastructure of mesophyll and bundle sheath chloroplast between control and salinity plus remission of potassium silicate. The control mesophyll chloroplasts were ellipsoidal and contained numerous well compartalized grana stacks. Little or no starch were present (Fig. 21a). Bundle sheath chloroplast of control plants is well developed as in mesophyll chloroplast and don't show any abnormalities in their ultrastructure. Unlike bundle sheath chloroplast, mesophyll chloroplast was hardly damage by salinity stress, while the structure of bundle sheath chloroplast was almost similar to control.

Salinity caused damage in structure of chloroplast, but degree was more marked in MC than BSC (Fig. 22 a \&b). The structure changes were particularly prominent in thylakoids, most MC chloroplast in salt treated plant exhibited thylakoid swelling and undulation of thylakoid membrane, also MC chloroplast exhibited disruption of chloroplast envelope. In barley leaf, almost little marked damages were observed in BSC chloroplast after salt treatment. The undulation of thylakoid membrane and swelling of thylakoid were observed on rare occasions, but the basic integrity was preserved. Since the low sensitivity of BSC chloroplast and high sensitivity of MC chloroplasts to salinity stress were reported in maize and several other species belong to NADP-ME type (Omoto et al., 2009). The ultrastructure studies of control leaf showed more or less intact plant cell as cell wall and cytoplasm appeared to be separated.

Plant grown with $\mathrm{NaCl}(200 \& 300 \mathrm{mM})$ had altered cell shape and altered disposition of cell plasma membrane. The plasma lemma was partially detached from cell wall at various position indicating plasmolysis. Plastoglobuli, which were greater in number and size in chloroplasts from leaves from the hypersaline site, may have been induced by lipid release upon thylakoid destruction under salt stress (Barhoumi et al., 2007) or due to premature cellular aging and senescence (Kelly et al., 1982). Increased plastoglobuli were also reported in chloroplasts of the mangrove Kandelia candel after salt treatment (Qiu et al., 2005). The ultrastructural changes observed mainly in the chloroplast of mesophyll cells of salt treated-plants suggest metabolic disorders in these organelles. It might be that the inhibition of enzymes of the photosynthesis carbon reduction cycle, which are known to be salt-sensitive, led to reduced photosynthesis and growth (Manetas 1990). 

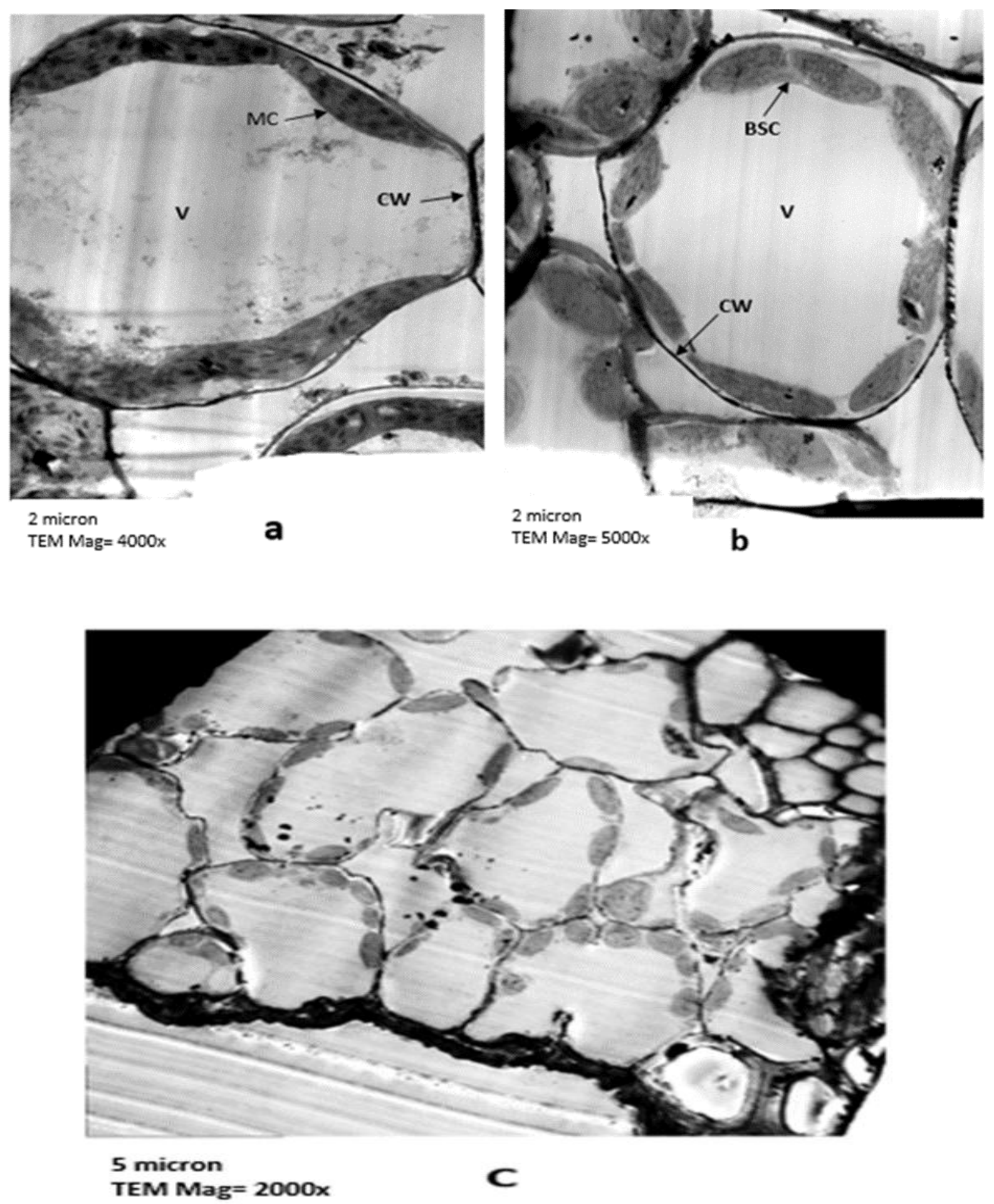

Fig. 21. Transmission electron microscope (TEM) micrograph in control barley leaf ultrastructure of mesophyll (a) and bundle sheath chloroplast (b \& c). $\mathrm{MC}=$ mesophyl chloroplast, $\mathrm{BSC}=$ bundle sheath chloroplast, $\mathrm{V}=$ vacuole, $\mathrm{CW}=$ cell wall. 

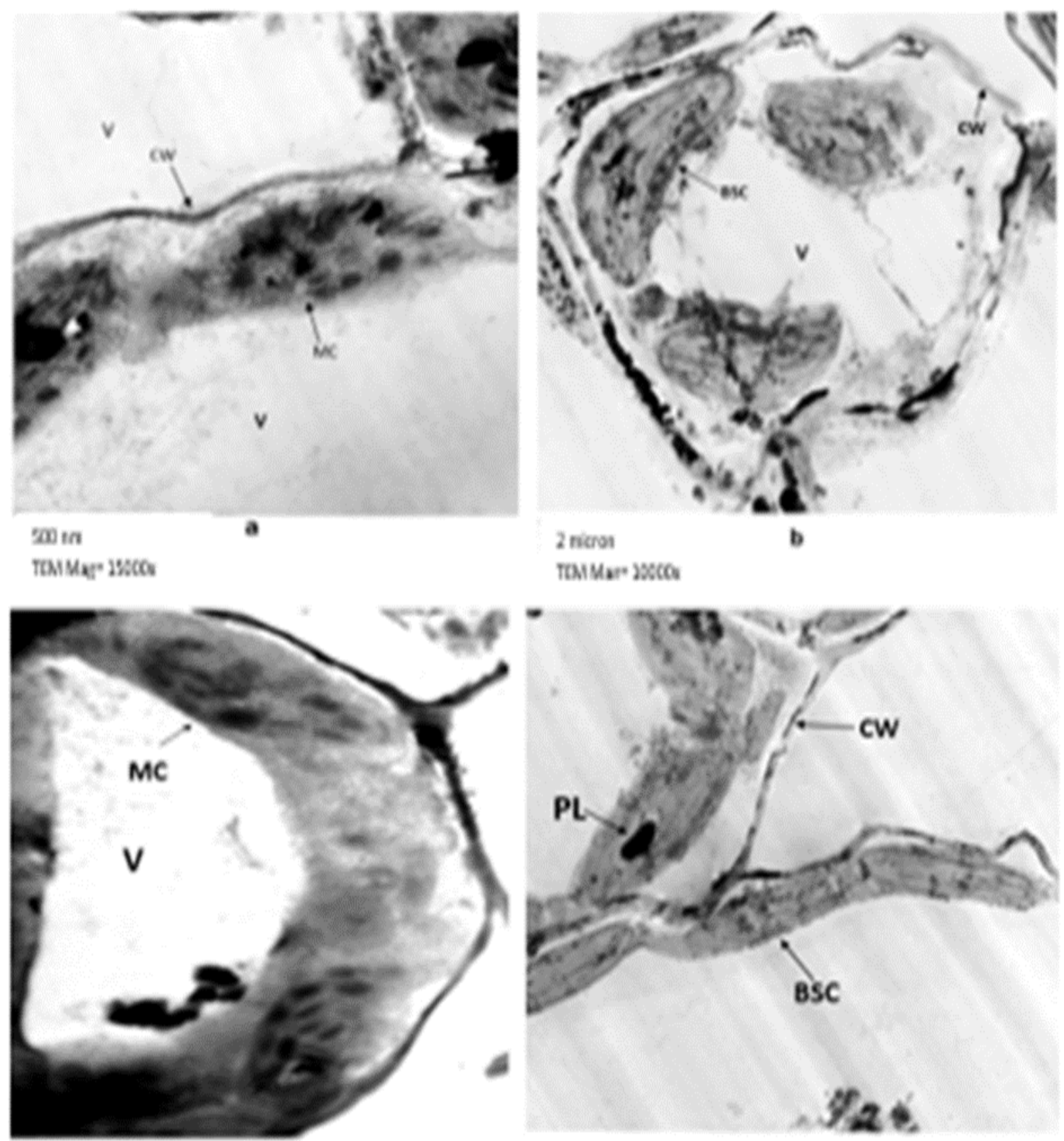

inise

C

2 nicros

TDMMer 2 XCo

d

Fig. 22. Transmission electron microscope micrograph in leaf ultrastructure of mesophyll (a \& c) and bundle sheath chloroplast (b \& d) of barley treated with $200 \& 300 \mathrm{mM} \mathrm{NaCl}$, respectively. $\mathrm{MC}=$ mesophyll chloroplast, $\mathrm{BSC}=$ bundle sheath chloroplast, $\mathrm{CW}=$ cell wall, $\mathrm{PL}=$ plastoglobule, $\mathrm{V}=$ vacuole. 
In addition to the discussion of $\mathrm{C} 4$ metabolism, the low sensitivity of bundle sheath chloroplasts to salt stress might be due to limited production of reactive oxygen species(ROS) because of limited non-cyclic electron flow and low conversion of $\mathrm{NADP}^{+}$to NADPH (Doulis et al., 1997). The products of photosynthesis are soluble sugar and starch, when plants exposed to salinity, their proportions may be adjusted to increase osmotic potential. Some investigators reported accumulation of sugar and depletion of starch (Zrenner and Stitt, 1991).

However, exogenous remission of $\mathrm{K}_{2} \mathrm{SiO}_{3} \cdot \mathrm{nH}_{2} \mathrm{O}$ alleviated the structural changes of chloroplasts induced by salt stress. Remission of $\mathrm{K}_{2} \mathrm{SiO}_{3} \cdot \mathrm{nH}_{2} \mathrm{O}$ maintained a wellpreserved internal lamellar system in the chloroplasts of salt-stressed leaves and the chloroplasts contained less osmiophilic plastoglobuli (Fig. 23 - 26). These results suggested that $\mathrm{K}_{2} \mathrm{SiO}_{3} . \quad \mathrm{nH}_{2} \mathrm{O}$ application helped to maintain the integrity of chloroplast ultrastructure, thus executed a normal physiological functions of the plant exposed to salt stress (Gengmao et al., 2015).

Maintaining structural integrity and orderliness of chloroplast is necessary in the conversion of light energy for photosynthesis. It was reported that many stressors led to the decrease in the photochemical efficiency and electron transport activity that might be associated with the changes of the structure of photosynthetic apparatus (Mittal, 2012).

In the present study, we observed that exogenous $\mathrm{Si}$ decreased the separation of plasma membrane from plasmolysis. Moreover, it commendably maintains the integrity of the plasma membrane. These results demonstrated that silicon was involved in protecting the photosynthetic apparatus. Our results also showed that photosynthetic activity in Honeysuckle (Lonicera japonica L.) was affected by salinity, and the extent of the reduction was dependent on the salt strength.

Zollinger (2007) found a similar reduction in photosynthetic rate and stomatal conductance in E. purpurea irrigated with increasing concentrations of salinity up to 5 $\mathrm{gL}^{-1}$. Reduction in photosynthetic rate under salinity can be attributed to both stomatal and nonstomatal limitations (Paranychianakis et al., 2005). In this study, we found a strong negative correlation between stomatal conductance and $\mathrm{Na}^{+}$concentrations both in the aboveground parts and roots, which indicates that plants tend to close their stomatal conductance as a result of specific-ion accumulations. This reduction in stomatal conductance led subsequently to a reduction in photosynthetic rate as indicated by the high correlation between stomatal conductance and photosynthetic rate. Gong et al., (2006) reported that silicon did not enhance the $\mathrm{K}+$ content of rice under salt stress. This is in agreement with our results that silicon had no effect on the $\mathrm{K}^{+}$concentration. It is well known that high concentrations of $\mathrm{Na}^{+}$can inhibit $\mathrm{K}+$ and $\mathrm{Ca}^{2+}$ uptake through antagonism between these ions 40. This fact can be attributed to their physicochemical similarity, which promotes ionic competition for binding sites on membrane transporters (Zhu, 2003). 

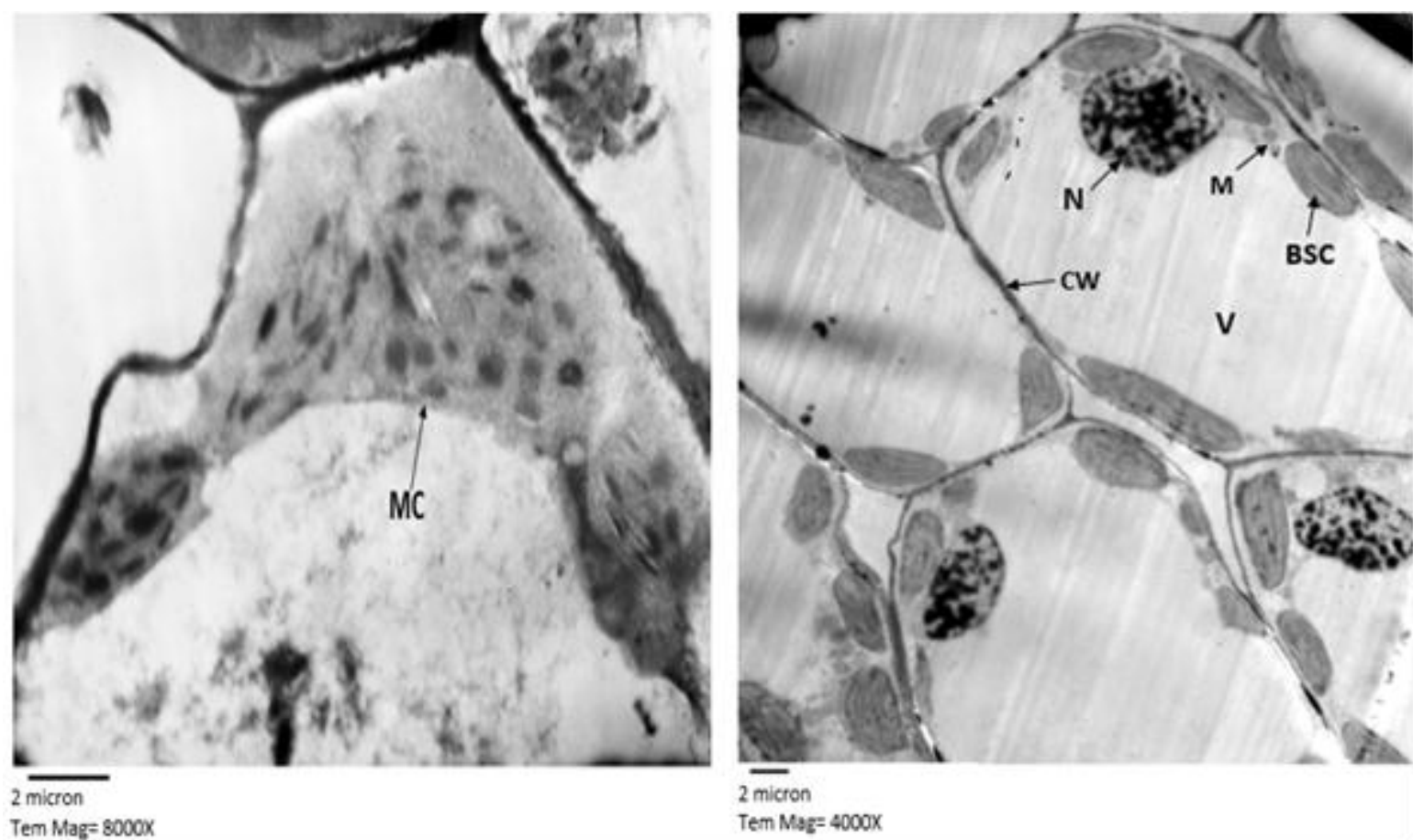

Fig. 23. Effect of salt stress $(\mathrm{NaCl} 200 \mathrm{mM})$ with exogenous remission of $\mathrm{k}_{2} \mathrm{SiO}_{3} \cdot \mathrm{nH}_{2} \mathrm{O}(0.5 \mathrm{mM})$ on mesophyll and bundle sheath chloroplast ultrastructure of barley leaves. $\mathrm{MC}=$ mesophyl chloroplast, $\mathrm{BSC}=$ bundle sheath chloroplast, $\mathrm{V}=$ vacuole, $\mathrm{CW}=$ cell wall, $\mathrm{N}=$ nucleus, $\mathrm{M}=$ mitochondria

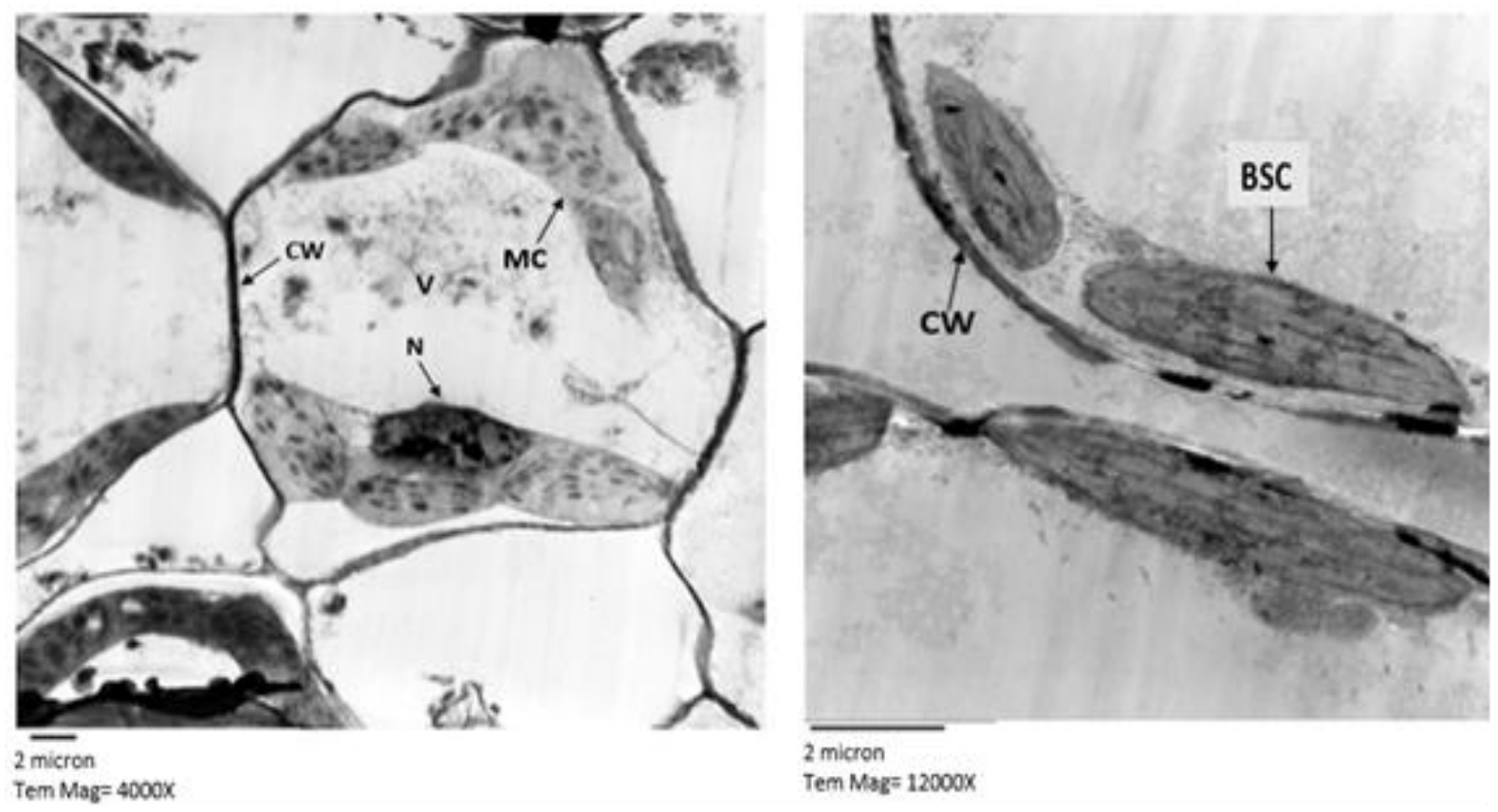

Fig. 24. Effect of salt stress $(\mathrm{NaCl} 200 \mathrm{mM})$ with exogenous remission of $\mathrm{k}_{2} \mathrm{SiO}_{3} \cdot \mathrm{nH}_{2} \mathrm{O}(1.0 \mathrm{mM})$ on mesophyll and bundle sheath chloroplast ultrastructure of barley leaves. 

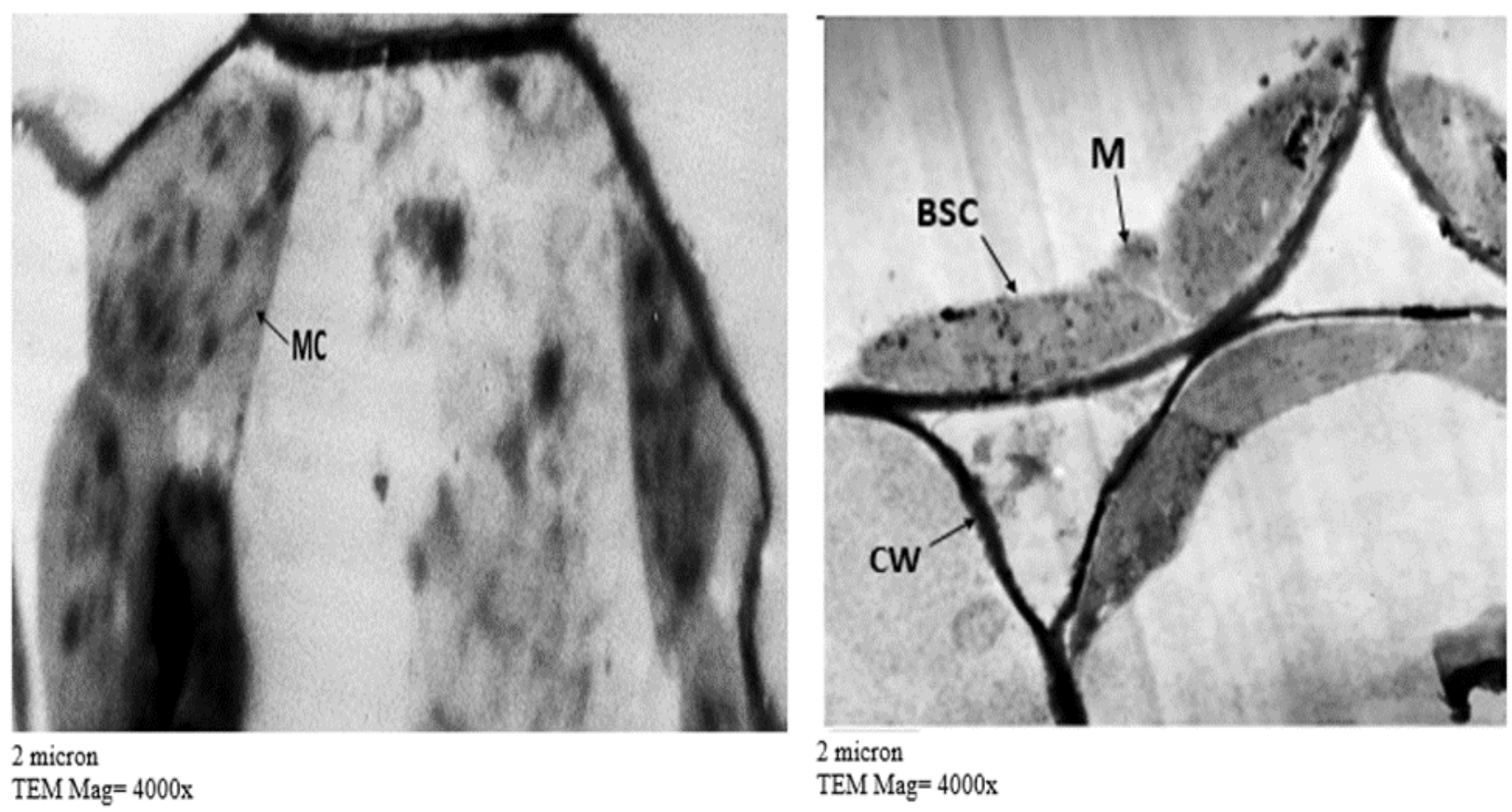

Fig. 25. Effect of salt stress $(\mathrm{NaCl} 300 \mathrm{mM})$ with exogenous remission of $\mathrm{k}_{2} \mathrm{SiO}_{3} \cdot \mathrm{nH}_{2} \mathrm{O}(0.5 \mathrm{mM})$ on mesophyll and bundle sheath chloroplast ultrastructure of barley leaves.
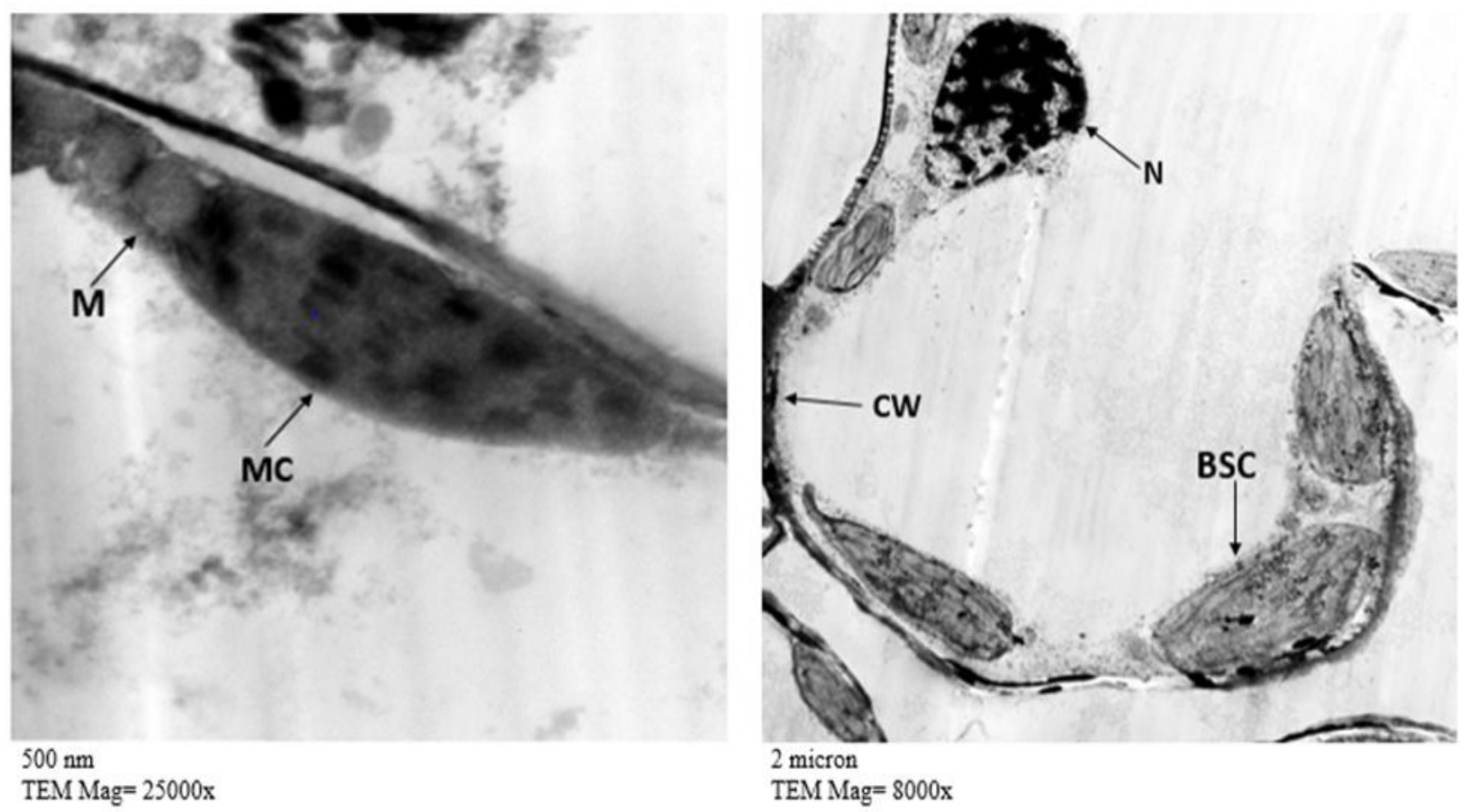

Fig. 26. Effect of salt stress $(\mathrm{NaCl} 300 \mathrm{mM})$ with exogenous remission of $\mathrm{k}_{2} \mathrm{SiO}_{3} \cdot \mathrm{nH}_{2} \mathrm{O}(1.0 \mathrm{mM})$ on mesophyll and bundle sheath chloroplast ultrastructure of barley leaves. 


\section{REFERENCES}

Agurie, S.; Agata, W.; Kubota, F. and Kaufman, P.B. (1992). Physiological role of silicon in photosynthesis and dry matter production in rice plants. Jpn. J. Crop. Sci. 61: 200-206.

Ahmad, R.; Zaheer, S.H. and Ismail, S. (1992). Role of silicon in salt toleranceof wheat (Triticum aestivum L.), Plant Sci. 85, 43-50.

Ahmad, S. and Haddad, R. (2011). Study of silicon effects on antioxidant enzyme activities and osmotic adjustment of wheat under drought stress. Czech J. Genet. Plant Breed. 47: 17-27.

Al-Aghabary, K.; Zhu, Z.J. and Shi, Q.H. (2004). Influence of silicon supplyon chlorophyll content, chlorophyll fluorescence and antioxidativeenzyme activities in tomato plants under salt stress, J. Plant Nutr.27 in press.

Ali1, A.; Basra, S.M.A.; Ahmad, R. and Wahid, A. (2009). Optimizing silicon application to improve salinity tolerance in wheat. Soil \& Environ. 28(2): 136-144.

Ashraf, M. and Ali. Q. (2008). Relative membrane permeability and activities of some antioxidant enzymes as the key determinants of salt tolerance in canola (Brassica napus L.). Environ. Exp. Bot., 63: 266-273.

Asmar, S.A. (2011). Sources of silicon in the development of micropropagated seedlings of banana 'Maçã'. Ciência Rural, v.41, n.7, p.1127-1131.

Barhoumi, Z.; Djebali, W.; Chai"bi, W.; Abdelly, C. and Smaoui, A. (2007). Salt impact on photosynthesis and leaf ultrastructure of Aeluropus littoralis. J. Plant Res., 120:529-537.

Bokhtiar, S.M.; Huang, H.; Li, Y. and Dalvi, V.A. (2012). Effects of silicon on yield contributing parameters and its accumulation in abaxial epidermis of sugarcane leaf blades using energy dispersive $\mathrm{x}$-ray analysis. J. Plant Nutr.; 35: 1255-1275.

Cakmak, I. and Marschner, H. (1992). Magnesium deficiency and highlight intensity enhance activities of superoxide dismutase ascorbate peroxidase, and glutathione reductase in bean leaves. Plant Physiol.; 98: 1222-1227.

Chapman, H. D. and Pratt, P. F. (1961). Methods of analysis for soils, plants and water. Univ. of California.

Chen, Z.; Zhou, M.; Newman, I.; Mendham, N.; Zhang, G. and Shabala, S. (2007). Potassium and sodium relations in salinised barley tissues as a basis of differential salt tolerance. Funct. Plant Biol. 34,150-162.

Currie, H.A. and Perry, C.C. (2007). Silica in plants: biological, biochemical and chemical studies. Annals of Botany, v.100, n.7, p.1383-1389.

Doulis, A. G.; Debia, N.; Kingston-Smith, A. H. and Foyer, C. H. (1997). Differential localisation of antioxidants in maize leaves. PlantPhysiol 114:1031-1037.

Elliot, C. L. and Snyder, G. H. (1991). Autoclave-induced digestion for the colorimetric determination of silicon in rice straw. Journal of Agriculture and Food Chemistry 39: 1118-1119.
FAO. (2017). Impacts of salinization, sodication and waterlogging. FAO Soils Portal. Feb. 13.

Farooq, S. and F. Azam. (2006). The use of cell membrane stability (CMS) technique to screen for salt tolerant wheat varieties. J. Plant Physiol., 163: 629-637.

Garcia, A.; Rizzo, C.A.; Ud-Din, J.; Bartos, S.L.; Senadhira, D.; Flowers, T.J. and Yeo, A.R. (1997). Sodium and potassium transport to the xylem are inherited independently in rice, and the mechanism of sodium: potassium selectivity differs between rice and wheat. - Plant Cell Environ. 20: 1167-1174.

Gengmao, Z.; Shihui1, L.; Xing, S.; Yizhou1, W. and Zipan, C. (2015). The role of silicon in physiology of the medicinal plant (Lonicera japonica L.) under salt stress. scientific report, 41, 1-10. www.nature.com/scintificreports.

Ghahfarokhi, M.G.; Mansurifar, S.; TaghizadehMehrjardi, R.; Saeidi, M.; Jamshidi, A. M. and Ghasemi, E. (2015). Effects of drought stress and rewatering on antioxidant systems and relative water content in different growth stages of maize hybrids. Archives of Agronomy and Soil Science; 61: 493-506.

Gong, H. J.; Randall, D. P. and Flowers, T. J. (2006). Silicon deposition in the root reduces sodium uptake in rice (Oryza sativa L.) seedlings by reducing bypass flow. Plant Cell Environ 29, 1970-1979 Plant Prod. Sci. 13(2): 169-176.

Gong, H.; Chen, K.; Chen, G.; Wang, S. and Zhang, C. (2003). Effects of silicon on growth of wheat under drought. J. of Plant Nutri., 26(5): 10551063.

Hakim, Y.; Khan, A.L.; Shinwari, Z.K.; Kim, D.; Waqas, M. and Lee, I. (2012). Silicon treatment to rice (Oryza sativa L.) plants during different growth periods and its effects on growth and grain yield. Pak. J. Bot.; 44: 891-897.

Hasanuzzaman, M.; Nahar, K.; Alam, M.M.; Roychowdhury, R. and Fujita, M. (2013). Physiological, biochemical, and molecular mechanisms of heat stress tolerance in plants. Int. J. Mol. Sci.; 14: 9643-9684.

Hoagland and Arnon (1950). The water-culture method for growing plants without soil. Berkeley, Calif.: University of California, College of Agriculture, Agricultural Experiment Station.

Kelly, D.B.; Goodin, J.R. and Miller, D.R. (1982). Contribution to the ecology of halophytes. Chapter 5. Biology of Atriplex. In: Sen, D.N., Rajpurohit, K.S. (Eds.), Tasks for Vegetation Science, vol. 2. The Hague, Junk, pp. 79-107.

Khan, M.J.; Rashid, H. and Ali R. (1999). Inter-varietal variability in wheat grown under saline conditions Pak. J. Biol. Sci., 2: 693-696.

Liang, Y.; Zhang, W.; Chen, Q. and Ding, R. (2005). Effect of silicon on H+-ATPase and H+-PPase activity, fatty acid composition and fluidity of tonoplast vesicles from roots of salt-stressed barley (Hordeum vulgare L.). J. Enviorn. Exp. Bot., 53: 29-37.

Liang, Y. C. (1998). Effects of silicon on leaf ultrastructure, chlorophyll content and 
photosynthetic activity in barley under salt stress, Pedosphere 8, 289-296.

Liang, Y.C. (1999). Effects of silicon on enzyme activity and sodium, potassium and calcium concentration in barley under salt stress. - Plant Soil 29: 217-224.

Liang, Y.C.; Chen, Q.; Liu, Q.; Zhang, W.H. and Ding, R.X. (2003). Exogenoussilicon (Si) increases antioxidant enzyme activity and reduces lipidperoxidation in roots of salt-stressed barley (Hordeum vulgare L.). J. Plant Physiol. $160,1157-1164$

Lopez, C.M.L.; Takahashi, H. and Yamazaki, S. (2002). Plant-water relations of kidney bean plants treated with $\mathrm{NaCl}$ and foliarly applied glycinebetaine. J. Agron. Crop Sci.188,73-80.

Ma, J. F. (2004). Role of silicon in enhancing the resistance of plants to biotic and abiotic stresses. Soil Sci. Plant Nutr.; 50:11-18.

Mali, M. and Aery, N.C. (2008). Influence of silicon on growth, relative water contents and uptake of silicon, calcium and potassium in wheat grown in nutrient solution. J. Plant Nutr., 31: 18671876.

Manetas, Y. (1990). A re-examination of $\mathrm{NaCl}$ effects on phosphoenol pyruvate carboxylase at high physiological enzyme concentrations. Physiol Plant 78:225-229.

McCune and Galston, A. W. (1989). Inverse effects of gibberellin on peroxidase activity and growth in dwarf strains of peas and corn'. Plant Physiol. 34: 416-418.

Metzner, H.; Rau, H. and Senger, H. (1965). Untersuchungen zur synchronisier barkeit einzelnerpigment. Mangol Mutanten von Chlorella, Planta, 65: 186.

Mittal, S.; Kumari, N. and Sharma, V. (2012). Diffrential response of salt stress on Brassice juncea: photosynthetic performance, pigment, proline, DI and antioxidant enzymes. Plant Physiol. Bioch., 54:17-26.

Munns, R. and M. Tester. 2008. Mechanisms of salinity tolerance. Annu. Rev. Plant Biol., 59: 651-81.

Nakano, Y. and Asada, K. (1987). Purification of ascorbate peroxidase in spinach chloroplasts: its inactivation in ascorbate- depleted medium and reactivation by monodehydroascorbate adical. Plant Cell Physiology. 28: 131-140.

Newman, C.W. and Newman, R.K. (2006). A brief history of barley foods. J. Cereal Foods World. 51(1): 4-7.

Niu, X.; Bressan, R.A.; Hasegawa, P.M. and Pardo, J.M. (1995). Ionhomeostasis in $\mathrm{NaCl}$ stress environments. Plant Physiol.,109, 735-742.

Noctor, G. and Foyer, C.H. (1998). Ascorbate and glutathione: keeping active oxygen under control. Annual Review of Plant Physiology and Plant Molecular Biology. 49: 249-279.

Omidi, H. (. 2010). Changes of proline content and activity of antioxidative enzymes in two canola genotype under drought stress. Am. J. Plant Physiol5: 338-349.

Omoto, E.; Kawasaki, M.; Taniguchi, M. and Miyake, H. (2009). Salinity induces granal development in bundle sheath chloroplasts of NADP-malic enzyme type C4 plants. Plant Prod. Sci. 12: 199207.

Oracaz, K.; Bailly, C.; Gniazdowska, A.; Come, D.; Corbineau, F. and Bogatek, R. (2007). Induction of oxidative stress by sunflower phytotoxins in germinating mustard seeds'. J. of Chemi. Ecol. 33:251-264.

Paranychianakis, N. V. and Chartzoulakis, K. S. (2005) Irrigation of Mediterranean crops with saline water: from physiology to management practices. Agr Ecosyst Environ 106, 171-187.

Qiu, D. L.; Lin, P. and Su, J. W. (2005). Relationship of leaf ultrastructure of mangrove Kandedelia candel (L.) Druce to salt tolerance. J. Forest Sci. 51, 476-480.

Reddy, A. R.; Chaitanya, K.V.; Jutur, P.P. and Sumithra, K. (2004). Differential antioxidative responses to water stress among five mulberry (Morus alba L.) cultivars. Environ. Exp. Bot. 52: 33-42.

Rezende, R. A. L. S.; Rodrigues, F. A.; Soares, J. D. R.; Silveira, H. R. D. O.; Pasqual, M. and Dias, G. M. G. (2018). Salt stress and exogenous silicon influence physiological and anatomical features of in vitro-grown cape gooseberry. Ciência Rural, Santa Maria, 48: (1) 1-9.

Richmond, K.E. and Sussman M. (2003). Got silicon? The non-essential benefical plant nutrient. Curr Opin Plant Biol; 6:268-72.

Ritchie, S. W. and Nguyen, H.T. (1990). Leaf water content and gas exchange parameters of two wheat genotypes differing in drought resistance. Crop Sci. 30: 105-111.

Romero-Arnada, M. R.; Jourado, O. and Cuartero, J. (2006). Silicon alleviates the deleterious salt effects on tomato plant growth by improving plant water status. J. Plant. Phy. 163(8): 847855.

Romero-Romero, T.; Sa'nchez-Nieto, S.; Sanjuan-Badillo, A.; Anaya, A.L. and Cruz-Ortega, R. (2005). Comparative effects of allelochemical and water stress in roots of Lycopersicon esculentum Mill. plant. Plant Sci. 168: 1059-1066.

Rueda-Puente, E.O.; Garc1 a-Herna ndez, J.L.; PreciadoRangel, P.; Murillo-Amador, B.; Tarazo' nHerrera, M.A.; Flores-Herna'ndez, A.; HolguinPeñ a, J.; Aybar, A. N.; Barro' n-Hoyos, J.M.; Weimers, D.; Mwandemele, O.; Kaaya, G.; Larrinaga-Mayoral, J. and Troyo-Die'guez, E. (2007). Germination of Salicornia bigelovii ecotypes under stressing conditions of temperature and salinity and ameliorative effects of plant growth-promoting bacteria. J. Agron. Crop Sci. 193, 167-176.

Sabatini, D. D.; Klaus Bensch, M. D.; Russell, J. and Barrnett, M. D. (1963). Cytochemistry and electron microscopy. Journal of cell biology. 17, $19-58$.

Sairam, R.K. and Srivastava, G.C. (2002). Changes in antioxidant activity in sub-cellular fractions of tolerant and susceptible wheat genotypes in response to long term salt stress. Plant Sci., 162: 897-904.

Santos, C.V. (2004). Regulation of chlorophyll biosynthesis and degradation by salt stress in sunflower leaves. Scientia Horticulturae, v.103, n.1, p.93-99. 
SAS (2004). Statistical Analysis System, SAS Institute, Inc. Cary, N. C. USA.

Sawas, D. and Ntatsi, G. (2015). Biostimulant activity of silicon in horticulture. Sci. Hortic. 196: 66-81.

Shao, H. B.; Chuc, L.Y.; Wu, G.; Zhang, J.H.; Lua, Z.H. and Hug, Y.C. (2007). Changes of some antioxidative physiological indices under soil water deficits among 10 wheat (Triticum aestivum L.) genotypes at tillering stage. Colloids Surf B Biointerfaces. 54:143-9.

Shu, L. Z. and Liu, Y. H. (2001). Effects of silicon on growth of maize seedlings under salt stress. Agro-environ.mental Prot., 20: 38-40.

Spurr, A. R. (1969). A low viscosity epoxy resin embedding medium for electron microscopy. J. Ultrastruct. Res. 26: 31-43.

Srinieng, K. (2015). Effect of salinity stress on antioxidative enzyme activities in tomato cultured in vitro. Pakistan Journal of Botany, .47 (1): $1-10$.

Tahir, M. A.; Aziz, R.T.; Ashraf, M.; Kanwal, S. and Maqsood, M. A. (2006). Beneficial effects of silicon in wheat (Triticum aestivum L.) under salinity stress. Pak. J. Bot. 38(5): 1715-1722.

Yasar, F. (2008). Effect of salt stress on antioxidant defense systems, lipid peroxidation, and chlorophyll content in green bean. Russian Journal of Plant Physiology, v.55, n.6, p.782786.

Yeo, A. R.; Flowers, S.A.; Rao, G.; Welfare, K.; Senanayake, N. and Flowers, T.J. (1999).
Silicon reduces sodium uptake in rice (Oryza sativa L.) in saline conditions and this is accounted for by a reduction in the transpirational by pass flow. Plant Cell Environ. $22,559-565$.

Zhou, M. X.; Johnson, P.; Zhoua, G.F.; Li, C. D., and Lance, R. (2012). Quantitative trait loci for waterlogging tolerance in a barley cross of Franklin $\times$ YuYaoXiangTianErleng and the relationship between waterlogging and salinity tolerance. Crop Sci. 52, 2082-2088.

Zhu, J. K. (2003). Regulation of ion homeostasis under salt stress. Curr opin plant biol 6, 441-445.

Zhu, Y. and Gong, H. (2014). Beneficial effects of silicon on salt and drought tolerance in plants. Agronomy for Sustainable Development, 34, (2) 455-472.

Zhu, Z.; Wei, G.; Li, J.; Qian, Q. and Yu, J. (2004). Silicon alleviates salt stress and increases antioxidant enzymes activity in leaves of saltstressed cucumber (Cucumis sativus L.). Plant Sci; $167: 527-33$.

Zollinger, S. A. (2007). Performance constraints and vocal complexity in birdsong: Evidence from a vocal mimic. Ph.D thesis, Indiana University.

Zrenner, R. and Stitt, T. M. (1991). Comparison of the effect of rapidly and gradually developing water-stress on carbohydrate metabolism in spinach leaves. Plant Cell Environ. 14:939-946.

تأثير السيلكا علي الخصائص الفسيولوجية و التركيب الدقيق للخليه لتبات الشعير تحت الإجهاد الملحي هند أحمد الخواجه

$$
\text { قسم النبات و الميكروبيولوجى - كلية العلوم - جامعة الأز هر -فرع البنات }
$$

أجريت هذه الدراسة بكلية الزراعة- جامعة الازهر. بهدف معرفة تأثير إضافة كلوريد الصوديوم

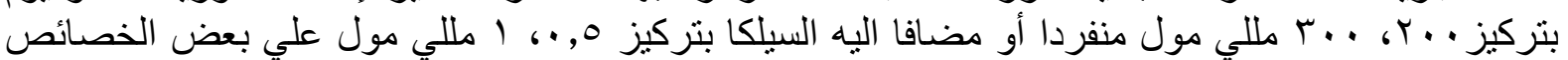

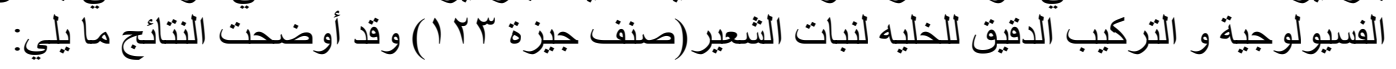

أدى استخدام كلوريد الصوديوم الى نقص معنوي للخصائص المرفولوجية، و نفاذية الجدار و المحتوي

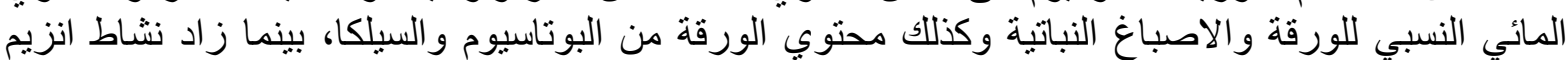

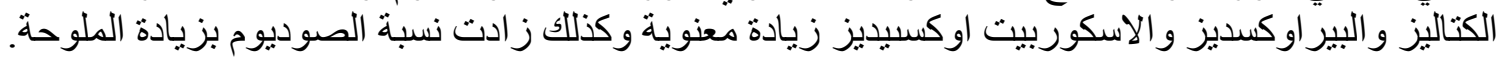

حدث بعض التغيرات الملحوظه في التركيب الدقيق للخلية بواسطة الميكروسكوب الالكتروني وخاصة

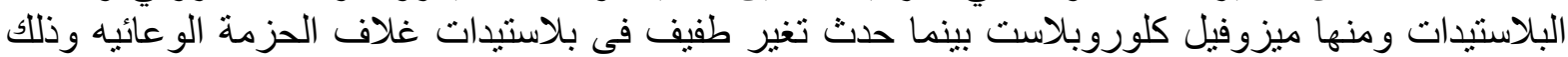

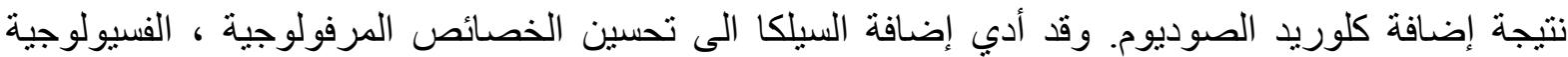

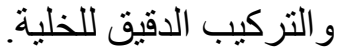

